\title{
Factors Influencing the Germination of Basidiospores of Coprinus radiatus
}

\author{
By G. L. MILLS AND F. I. EILERS \\ Department of Biology, \\ University of South Florida, Tampa, Florida, U.S.A. \\ (Received 27 March 1972; revised 5 February 1973)

\begin{abstract}
SUMMARY
Constitutional dormancy is demonstrated for basidiospores of Coprinus radiatus. Germination can be induced by heat and certain chemicals. Heating spores to $45{ }^{\circ} \mathrm{C}$ for $4 \mathrm{~h}$ results in $23 \%$ germination and treatment with a variety of chemicals yields about $3 \%$. Germination in spores which are first heated and subsequently treated with chemicals is either similar to that in heated spores $(23 \%)$ or slightly higher $(33 \%)$, while spores which are heated in the presence of chemical show germination percentages up to $88 \%$.
\end{abstract}

\section{INTRODUCTION}

Fungal spores may be divided into two major groups: those which will germinate under conditions favouring vegetative growth and those which will not. Dormancy of the former type is termed exogenous (Sussman \& Halvorson, 1966). The second group of spores exhibits a constitutional dormancy which is more complex and seems to be attributable to an innate property of the spore itself, such as a barrier to nutrient penetration, a metabolic block, or the production of a self-inhibitor. A number of physical factors (e.g. temperature, light) or chemical factors will break constitutional dormancy (Sussman \& Halvorson, 1966).

While constitutional dormancy has been described in several basidiomycetes, none of those examined has been found to be suitable for investigations of the germination process. In this paper, we report an exception.

\section{METHODS}

Organism and conditions of growth. The fungus used was Coprinus radiatus (culture number c. I3/I) from the collection of Dr R. Kemp, University of Edinburgh. It was grown in pure culture on $20 \mathrm{ml}$ of horse-dung medium (Lange, 1952) in $125 \mathrm{ml}$ Erlenmeyer flasks. The inoculum consisted of fragments of the vegetative mycelium. All cultures were maintained at room temperature and no attempt was made to control light or humidity. Mature fruiting bodies were obtained in 8 to 14 days.

Spore collection. Mature caps were placed in flasks of distilled water and refrigerated until the caps auto-digested. This slurry was gently homogenized in a Ten Brock homogenizer and filtered twice through glass wool. The spores in the filtrate were washed with distilled $\mathrm{H}_{2} \mathrm{O}$ and concentrated by centrifugation. The spores were then resuspended in a minimum amount of water, poured into a Petri dish, covered, and air-dried. Spores collected in this manner were free from visible mycelial debris. After air-drying, one group of spores was stored at $22{ }^{\circ} \mathrm{C}$ and a second group at $8{ }^{\circ} \mathrm{C}$ for up to Io months before use. 


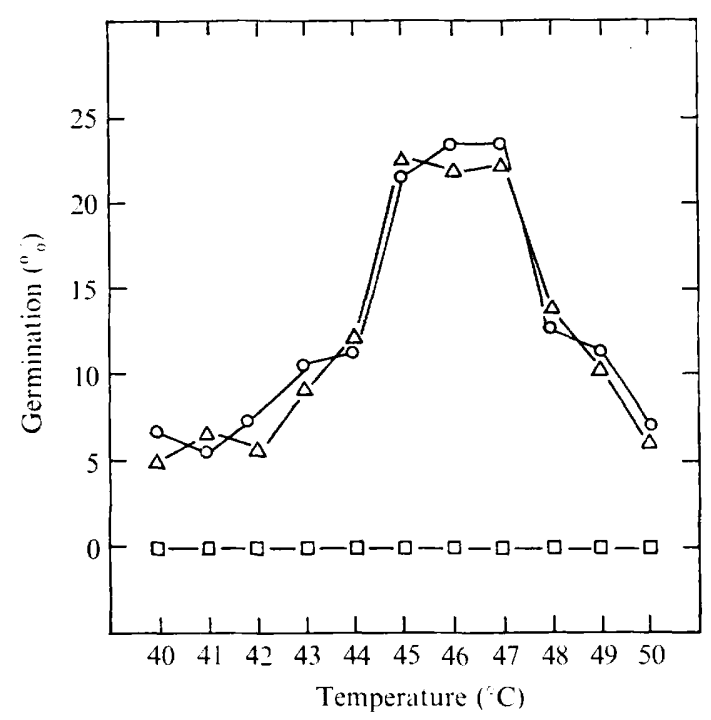

Fig. I. Spore germination induced by temperatures between 40 and $50{ }^{\circ} \mathrm{C}$. Two separate spore groups were heated at each temperature for $4 \mathrm{~h}$, cooled, and incubated further at room temperature. The points represent maximum germination. $\triangle$, Spores stored at $8{ }^{\circ} \mathrm{C} ; \mathrm{O}$, spores stored at room temperature; $\square$, control spores (non-heated).

Measurement of germination. The criterion of germination was the appearance of a germ tube. Samples of the various treatments were observed microscopically in a Bright Line haemocytometer and 500 spores were scored.

Chemicals. The following chemicals were employed in germination tests: furfural, 2-furfuryl alcohol, furoic acid (Aldrich Chemical Co., Milwaukee, Wisconsin, U.S.A.); 2-methyl furan, 2-furfural acrolein, 5-methyl furfural, 5-hydroxymethyl furfural, methyl2-furoate (Quaker Oats Laboratories, Chicago, Illinois, U.S.A.); 2-furfuryl methyl ether, $n$-propyl furoate, 2-furfuryl-n-butyrate, 2-furfuryl diacetate (Eaton Laboratories, Norwich, New York, U.S.A.); thiophene, 2-thiophene carboxaldehyde, pyrrole (Eastman Kodak, Rochester, New York, U.S.A.); benzaldehyde (Mallenchrodt Chemical Works, St Louis, Missiouri, U.S.A.); phenethyl alcohol (Matheson, Coleman \& Bell, Norwood, Ohio, U.S.A.). Some of these chemicals were redistilled before use.

\section{RESULTS}

Determination of the dormancy type in Coprinus radiatus. When samples of the collected or naturally shed basidiospores (uncontaminated with vegetative mycelia) of Coprinus radiatus were placed in sterile liquid, or on solid culture media with no prior treatment, germination did not occur. Pieces of vegetative tissue, however, initiated extensive growth on the same medium, therefore these spores probably possessed the more complex constitutional type of dormancy. Spores were treated with heat or chemicals or both, because similar treatments are known to break constitutional dormancy in other fungi (Sussman, 1965; Sussman \& Halvorson, I966) and $37^{\circ} \mathrm{C}$ is used to induce germination of $C$. radiatus spores in genetic studies (Gans \& Masson, 1969).

Heat treatment as a means of activation. To test the effects of heat on the induction of germination, basidiospores were incubated at several temperatures for various periods. Spores $(1.0 \mathrm{mg})$ were placed in $2 \mathrm{ml}$ of distilled water $\left(\mathrm{I} .75 \times 10^{6}\right.$ spores $\left./ \mathrm{ml}\right)$ in $25 \mathrm{ml}$ 


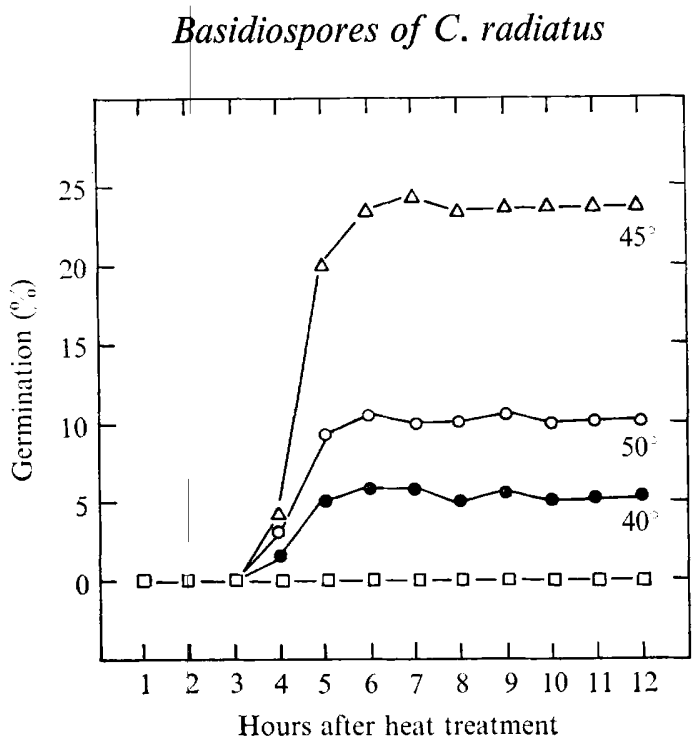

Fig. 2. Kinetics of spore germination after heat treatment. Basidiospores were heated in distilled water for $4 \mathrm{~h}$ at $40^{\circ} \mathrm{C}(\mathrm{O}), 45^{\circ} \mathrm{C}(\triangle)$ and $50^{\circ} \mathrm{C}(\mathrm{O})$, and then compared with spores left at room temperature ( $\square)$.

Table I. Heat-induced germination of spores of Coprinus radiatus in the presence and absence of exogenous nutrients

\begin{tabular}{|c|c|c|c|}
\hline $\begin{array}{c}\text { Temperature } \\
\left({ }^{\circ} \mathrm{C}\right)\end{array}$ & $\begin{array}{l}\text { Time of } \\
\text { heating }\end{array}$ & $\begin{array}{c}\text { Average } \\
\text { spore } \\
\text { germination } \\
\text { in distilled } \\
\text { water } \\
(\%)\end{array}$ & $\begin{array}{c}\text { Average } \\
\text { spore } \\
\text { germination } \\
\text { on horse- } \\
\text { dung agar } \\
\text { medium } \\
(\%)\end{array}$ \\
\hline 30 & $4 h$ & 0.8 & 0.8 \\
\hline 35 & $4 \mathrm{~h}$ & 0.9 & 0.8 \\
\hline 40 & $4 \mathrm{~h}$ & $4 \cdot 0$ & $4^{\circ} 0$ \\
\hline 45 & $4 \mathrm{~h}$ & $23 \cdot 0$ & 24.0 \\
\hline 50 & $4 \mathrm{~h}$ & $8 \cdot 0$ & $7 \cdot 0$ \\
\hline 55 & $30 \mathrm{~min}$ & $I \cdot I$ & $I \cdot 0$ \\
\hline 60 & $20 \mathrm{~min}$ & 0.5 & 0.4 \\
\hline
\end{tabular}

Germination percentages based on counts of 500 spores each, from two separate spore populations.

Erlenmeyer flasks. Flasks were then heated in a water bath at temperatures from 30 to $60{ }^{\circ} \mathrm{C}$ in $5{ }^{\circ} \mathrm{C}$ increments. At seven intervals (hourly for $30,35,40,45$ and $50{ }^{\circ} \mathrm{C}, 30 \mathrm{~min}$ for $55^{\circ} \mathrm{C}$, and $10 \mathrm{~min}$ for $60^{\circ} \mathrm{C}$ ), samples were removed, maintained at room temperature, and examined for germination. Some spore germination occurred at all temperatures, the greatest increase occurring in samples heated to $45^{\circ} \mathrm{C}$ for $4 \mathrm{~h}$. From this initial experiment the temperature range between 40 to $50^{\circ} \mathrm{C}$ seemed the most effective and was re-examined at $\mathrm{I}^{\circ} \mathrm{C}$ intervals. These results, shown in Fig. I, indicate a narrow optimal activation-temperature range of 45 to $47^{\circ} \mathrm{C}$.

Maximum germination was approximately $23 \%$. To rule out self-inhibitor effects, concentrations of $5.0 \mathrm{mg} / \mathrm{ml}$ and $0.05 \mathrm{mg} / \mathrm{ml}$ were also tested at $46^{\circ} \mathrm{C}$ and germination was the same as with $0.5 \mathrm{mg}$ spores $/ \mathrm{ml}$. The failure of most spores to germinate was probably not ascribable to immaturity because spores of a more thoroughly studied species, 
Table 2. Stimulation of germination of spores of Coprinus radiatus by various heterocyclic, aromatic and aliphatic chemicals

\begin{tabular}{|c|c|c|c|c|c|c|c|}
\hline \multirow[b]{2}{*}{ Chemical } & \multicolumn{3}{|c|}{ Chemical treatment } & \multicolumn{2}{|c|}{$\begin{array}{c}\begin{array}{c}\text { Sequential heat/ } \\
\text { chemical treatments }\end{array}\end{array}$} & \multicolumn{2}{|c|}{$\begin{array}{l}\text { Stimultaneous heat/ } \\
\text { chemical treatment }\end{array}$} \\
\hline & Formula & $\begin{array}{l}\text { Optimal } \\
\text { molar } \\
\text { concen- } \\
\text { tration }\end{array}$ & $\begin{array}{l}\text { Germina- } \\
\text { tion }(\%)\end{array}$ & $\begin{array}{l}\text { Optimal } \\
\text { molar } \\
\text { concen- } \\
\text { tration }\end{array}$ & $\begin{array}{l}\text { Germina- } \\
\text { tion }(\%)\end{array}$ & $\begin{array}{l}\text { Concen- } \\
\text { tration }\end{array}$ & $\begin{array}{c}\text { Germina- } \\
\text { tion }(\%)\end{array}$ \\
\hline $\begin{array}{l}\text { Furfural } \\
\text { 2-Furfuryl }\end{array}$ & RCHO & $1 \times 10^{-3}$ & $1 \cdot 9$ & $1 \times 10^{-3}$ & $3 I$ & $1 \times 10^{-3}$ & 88 \\
\hline $\begin{array}{l}\text { alcohol } \\
\text { 5-Hydroxymethyl }\end{array}$ & $\mathrm{RCH}_{2} \mathrm{OH}$ & $\mathrm{I} \times 10^{-3}$ & $2 \cdot 8$ & $\mathrm{I} \times 10^{-3}$ & 29 & $1 \times 10^{-3}$ & 80 \\
\hline furfural & $\mathrm{CH}_{2} \mathrm{OHRCHO}$ & $1 \times 10^{-3}$ & $2 \cdot 2$ & $\mathrm{I} \times 10^{-3}$ & 33 & $I \times 10^{-3}$ & 66 \\
\hline Thiophene & $\mathrm{R}^{\prime} \mathrm{H}$ & $1 \times 10^{-3}$ & $\mathrm{I} \cdot 7$ & $I \times 10^{-3}$ & 33 & $1 \times 10^{-3}$ & 76 \\
\hline Pyrrole & $\mathrm{R}^{\prime \prime} \mathrm{H}$ & $1 \times 10^{-3}$ & $2 \cdot 4$ & $1 \times 10^{-3}$ & 31 & $1 \times 10^{-3}$ & 75 \\
\hline Benzaldehyde & $\mathrm{R}^{\prime \prime \prime} \mathrm{CHO}$ & $1 \times 10^{-3}$ & $2 \cdot 4$ & $1 \times 10^{-3}$ & 32 & $1 \times 10^{-3}$ & 76 \\
\hline 2-Methyl furan & $\mathrm{RCH}_{3}$ & $1 \times 10^{-3}$ & $1 \cdot 4$ & $1 \times 10^{-3}$ & 29 & $1 \times 10^{-3}$ & 59 \\
\hline 5-Methyl furfural & $\mathrm{CH}_{3} \mathrm{RCHO}$ & $I \times 10^{-3}$ & $\mathrm{I} \cdot 7$ & $1 \times 10^{-3}$ & 26 & $\mathbf{I} \times 10^{-3}$ & 52 \\
\hline Methyl 2-furoate & $\mathrm{RCOOCH}_{3}$ & $1 \times 10^{-4}$ & $2 \cdot 0$ & $\mathrm{I} \times 1 \mathrm{IO}^{-3}$ & 27 & $1 \times 10^{-3}$ & 56 \\
\hline $\begin{array}{l}\text { 2-Furfuryl } \\
\text { diacetate } \\
\text { 2-Thiophene }\end{array}$ & $\mathrm{RCH}\left\langle\underset{\mathrm{COOCH}_{3}}{\mathrm{COOCH}_{3}}\right.$ & $1 \times 10^{-4}$ & $2 \cdot 2$ & $\mathrm{I} \times 1 \mathrm{IO}^{-3}$ & 28 & $1 \times 10^{-3}$ & 42 \\
\hline $\begin{array}{l}\text { carboxaldehyde } \\
\text { 2-Furfuryl }\end{array}$ & $\mathrm{R}^{\prime} \mathrm{CHO}$ & $\mathrm{I} \times \mathrm{IO}^{-3}$ & $2 \cdot 2$ & $1 \times 10^{-3}$ & 27 & $1 \times 10^{-3}$ & 56 \\
\hline $\begin{array}{l}\text { methyl ether } \\
\text { 2-Furfural }\end{array}$ & $\mathrm{RCH}_{2} \mathrm{OCH}_{3}$ & $1 \times 10^{-3}$ & $I \cdot I$ & $\mathrm{I} \times 10^{-3}$ & 26 & $1 \times 10^{-3}$ & 34 \\
\hline $\begin{array}{l}\text { acrolein } \\
n \text {-propyl furoate }\end{array}$ & $\begin{array}{l}\text { RCNCHCHO } \\
\mathrm{RCOOCH}_{3} \mathrm{CH}_{2}\end{array}$ & $I \times 10^{-3}$ & $\mathrm{I} \cdot 7$ & $1 \times 10^{-3}$ & 20 & $I \times 10^{-3}$ & 30 \\
\hline 2-Furfuryl-n- & $\mathrm{CH}_{3}$ & $I \times 10^{-3}$ & $1 \cdot 9$ & $\mathrm{I} \times \mathrm{IO}^{-3}$ & 25 & $\mathrm{I} \times \mathrm{IO}^{-3}$ & 36 \\
\hline butyrate & $\mathrm{RCH}_{2} \mathrm{OCOC}_{3} \mathrm{H}_{7}$ & $\mathrm{I} \times \mathrm{IO}^{-4}$ & $2 \cdot 2$ & $\mathrm{I} \times \mathrm{IO}^{-3}$ & 29 & $\mathrm{I} \times \mathrm{IO}^{-3}$ & 40 \\
\hline Furoic acid & $\mathrm{RCOOH}$ & $1 \times 10^{-4}$ & $I \cdot 4$ & $I \times 10^{-3}$ & $2 \mathrm{I}$ & $\mathrm{I} \times 10^{-3}$ & 30 \\
\hline Phenethyl alcohol & $\mathrm{R}^{\prime \prime \prime} \mathrm{CH}_{2} \mathrm{CH}_{2} \mathrm{OH}$ & $\mathrm{I} \times 1 \mathrm{IO}^{-3}$ & $2 \cdot 4$ & $\mathbf{I} \times 10^{-3}$ & 30 & $\mathrm{I} \times 1 \mathrm{IO}^{-3}$ & 29 \\
\hline Acetone & $\mathrm{CH}_{3} \mathrm{COCH}_{3}$ & 5 & $2 \cdot 4$ & 10 & 26 & Io & 30 \\
\hline Ethanol & $\mathrm{CH}_{3} \mathrm{CH}_{2} \mathrm{OH}$ & 10 & $3 \cdot 0$ & 10 & 30 & 10 & 31 \\
\hline $\mathrm{R}=\|_{\mathrm{HC}}^{\mathrm{HC}}$ & $\mathbf{R}^{\prime}$ & $\begin{array}{cc}\mathrm{HC} & \mathrm{CF} \\
\mathrm{HC} & \mathrm{CH}\end{array}$ & $\mathrm{R}^{\prime \prime}=$ & & $\mathbf{R}^{\prime \prime \prime}=$ & C & \\
\hline
\end{tabular}

Coprinus lagopus, have been reported to be $85 \%$ synchronous in development (Raju \& Lu, 1970).

Kinetics of spore germination. The rate of spore germination was determined for spores heated to 40,45 and $50^{\circ} \mathrm{C}$. In these experiments, spores were checked hourly during the heating process and during subsequent incubation at room temperature. No germination occurred as the spores were being heated. In all instances there was a 3 to $4 \mathrm{~h}$ lag at room temperature before germination was observed (Fig. 2). Once germination began, the spores exhibited a near synchronous response. Additional germinations did not occur beyond $6 \mathrm{~h}$.

As Coprinus radiatus is a coprophilous fungus, its spores are heated to 38 to $42{ }^{\circ} \mathrm{C}$ as they pass through the alimentary tract of mammalian herbivores. Consequently, exposure to these temperatures for prolonged periods might substitute for shorter exposures at higher temperatures. To test this possibility, spores were incubated at $40{ }^{\circ} \mathrm{C}$ for periods up to 


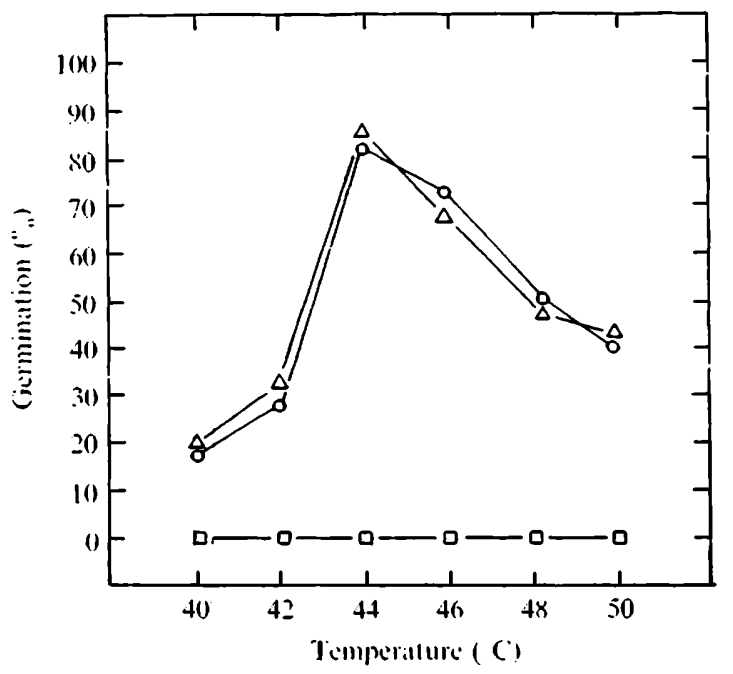

Fig. 3. The optimal temperature range for spore germination when spores were simultaneously heated and chemically treated. $\triangle$, Spores stored at room temperature; $O$, spores stored at $8{ }^{\circ} \mathrm{C}$; $\square$, untreated control spores.

$72 \mathrm{~h}$. This produced no increase in germination beyond that found at shorter periods at the same temperature (Fig. I).

Nutritional requirements for germination. Although horse-dung medium at $25^{\circ} \mathrm{C}$ did not induce germination, the possibility remained that certain nutritional requirements may have restricted germination to a maximum of $23 \%$ when heated. This possibility was discounted by heating spores in distilled water at temperatures of 30 to $60^{\circ} \mathrm{C}$ and then plating half of the spores on horse-dung agar medium. At each temperature the same number of spores germinated in each medium (Table I). Apparently the restraint on germination above $23 \%$ was not caused by a nutritional difference.

Chemical treatment as means of spore activation. Because others (Sussman, 1953; Lingappa, Lingappa \& Turian, 1970) have shown that various chemical agents can break constitutional dormancy we tested several of the same compounds on Coprinus radiatus. Several heterocyclic and aromatic compounds were applied in concentrations ranging from $10^{-1}$ to $10^{-6} \mathrm{M}$. Spores were incubated in each agent for $12 \mathrm{~h}$ (Table 2). All the compounds tested prompted some germination above control level when applied in the range of $\mathrm{IO}^{-3}$ to $1 \mathrm{O}^{-4} \mathrm{M}$. The response was between $\mathrm{I}$ and $3 \%$.

Ethanol and acetone induce germination in Neurospora ascospores (Sussman, Lowry \& Tyrrell, 1959) and so were tested with these spores. Spores were incubated in concentrations of $1,5,10$ and 15 M-ethanol or acetone for $30 \mathrm{~min}, 1,2$ and $16 \mathrm{~h}$, then washed in distilled water and resuspended in $2 \mathrm{ml}$ of distilled water for an additional $\mathrm{I} 2 \mathrm{~h}$ before scoring. Like the previous compounds, these solvents activated only a few spores. The maximum values are shown in Table 2. The results were very uniform. At the highest concentrations, some toxicity was apparent as no germination was observed (e.g. in acetone at $15 \mathrm{M}$ for $16 \mathrm{~h}$ ).

To determine if low germination was caused by chemical toxicity, spores which had been subjected to a $\mathrm{I} 2 \mathrm{~h}$ exposure to furfural and furoic acid $\left(\mathrm{IO}^{-1}\right.$ to $\left.1 \mathrm{IO}^{-6} \mathrm{M}\right)$ were subsequently heated to $45^{\circ} \mathrm{C}$ for $4 \mathrm{~h}$. Except at $10^{-1} \mathrm{M}$, spores heated with furfural gave maximal percentages of germination identical with those exhibited by heated spores (Fig. I). Furoic acid-treated spores showed more extensive toxic effects with no germination at $10^{-1} \mathrm{M}$ 


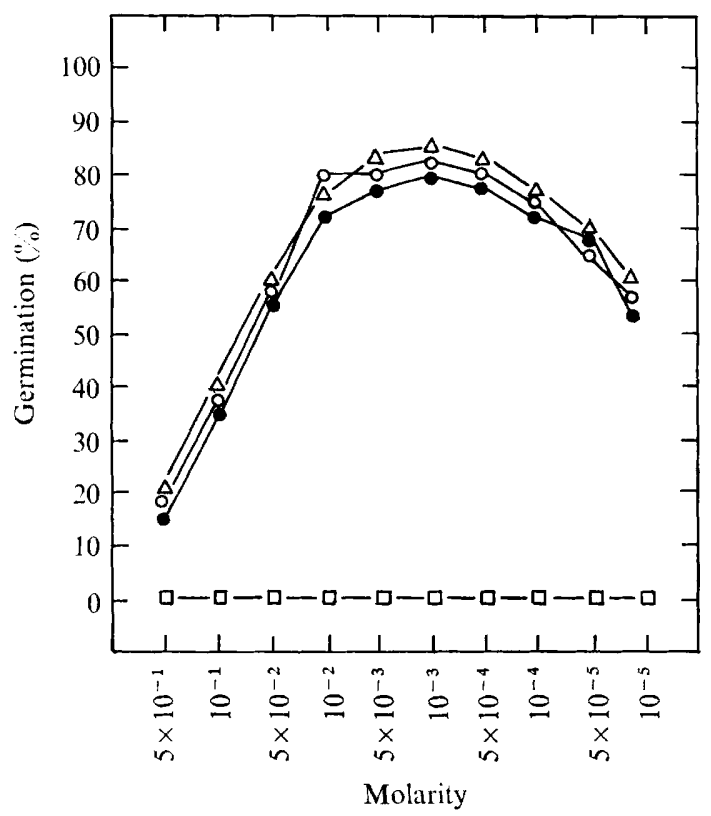

Fig. 4. The induction of germination by various concentrations of chemical when spores were simultaneously heated and chemically treated. $\triangle$, Furfural; 0 , thiophene; $\boldsymbol{\theta}$, pyrrole; and $\square$, untreated controls.

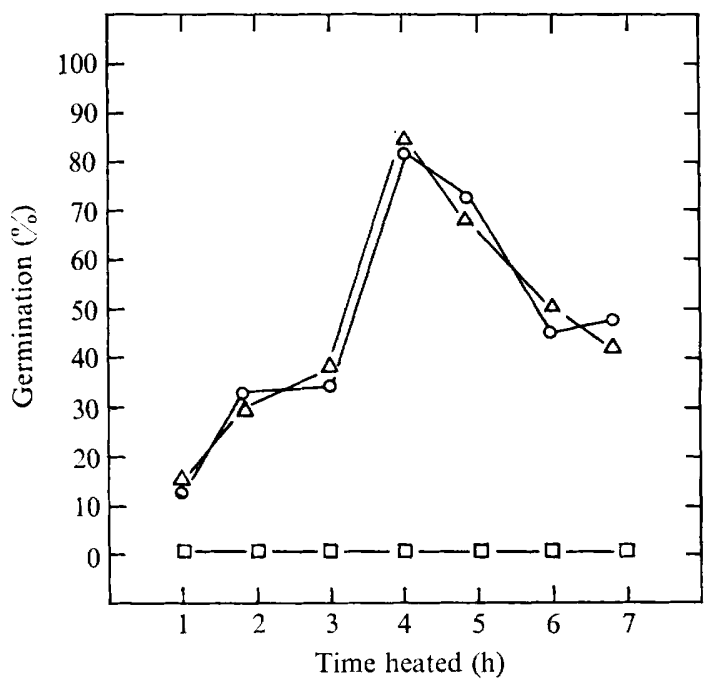

Fig. 5. The effect of heating time when spores were simultaneously heated at $44^{\circ} \mathrm{C}$ and treated with $10^{-3} \mathrm{M}$-furfural. $\triangle$, Spores stored at room temperature; $O$, spores stored at $8^{\circ} \mathrm{C} ; \square$, untreated control spores.

and reduced germination ( $13 \%$ ) at $10^{-2}$ and $10^{-3} \mathrm{M}$. However, at lower concentrations, germination was the same as with heated spores. Consequently the relatively low percentage of germination induced by chemicals did not seem to be caused by toxicity.

Combination of heat and chemical treatment. While heat or chemicals alone can produce low percentages of spore germination, together they might prove additive or even synergistic. 
Table 3. Comparison of activation methods for constitutionally dormant spores of Coprinus, Neurospora, and Phycomyces

\begin{tabular}{|c|c|c|c|c|c|c|c|}
\hline \multirow{2}{*}{\multicolumn{2}{|c|}{ Organism }} & \multicolumn{6}{|c|}{ HEAT } \\
\hline & & $\begin{array}{l}\text { Optimum } \\
\text { temperature } \\
\left({ }^{\circ} \mathrm{C}\right)\end{array}$ & $\begin{array}{l}\text { Maximum } \\
\text { response } \\
(\%)\end{array}$ & \multicolumn{2}{|c|}{$\begin{array}{l}\text { Time required to } \\
\text { induce maximum } \\
\text { germination }\end{array}$} & \multicolumn{2}{|c|}{$\begin{array}{c}\text { Time interval } \\
\text { between induction } \\
\text { and germination }(\mathrm{h})\end{array}$} \\
\hline Copr & & 44 to 46 & \multirow[t]{2}{*}{23} & \multicolumn{2}{|c|}{$4 \mathrm{~h}$} & & 4 to 6 \\
\hline Neur & spora & 50 to 60 & & \multicolumn{2}{|c|}{10 to $20 \mathrm{~min}$} & & 3 \\
\hline Phyc & myces & 50 & 80 & \multicolumn{2}{|c|}{$3 \mathrm{~min}$} & & 3 \\
\hline \multicolumn{8}{|c|}{ CHEMICALS } \\
\hline Orga & hism & $\begin{array}{l}\text { Optimum } \\
\text { concentration } \\
\text { range (M) }\end{array}$ & $\begin{array}{c}\text { Maximum } \\
\text { response } \\
(\%)\end{array}$ & \multicolumn{4}{|c|}{$\begin{array}{l}\text { Time interval } \\
\text { between induction } \\
\text { and germination }(\mathrm{h})\end{array}$} \\
\hline Copr & & $10^{-2}$ to $10^{-4}$ & 3 & \multicolumn{2}{|c|}{$\begin{array}{l}\text { Furfural and other } \\
\text { heterocyclics }\end{array}$} & \multicolumn{2}{|c|}{4 to 6} \\
\hline $\begin{array}{l}\text { Neur } \\
\text { Phyc }\end{array}$ & $\begin{array}{l}\text { spora } \\
\text { myces }\end{array}$ & $10^{-2}$ to $10^{-4}$ & $\underline{90}$ & \multicolumn{2}{|c|}{ Organic solvents } & & $\frac{3}{-}$ \\
\hline \multicolumn{8}{|c|}{ HEAT AND CHEMICALS } \\
\hline ism & $\begin{array}{l}\text { Temperature } \\
\left({ }^{\circ} \mathrm{C}\right)\end{array}$ & $\begin{array}{l}\text { Time of heat } \\
\text { treatment }\end{array}$ & $\begin{array}{l}\text { Chemical } \\
\text { concentration } \\
\text { (M) }\end{array}$ & $\begin{array}{l}\text { Response } \\
\text { stimuli follow } \\
\text { each other } \\
(\%)\end{array}$ & $\begin{array}{r}\text { Respon } \\
\text { stimuli ap } \\
\text { togethe } \\
(\%)\end{array}$ & $\begin{array}{l}\text { Ise } \\
\text { plied } \\
\text { er }\end{array}$ & $\begin{array}{l}\text { Time between } \\
\text { induction and } \\
\text { germination }(\mathrm{h})\end{array}$ \\
\hline & 44 to 46 & $4 \mathrm{~h}$ & $10^{-3}$ & 33 & 88 & & 4 to 6 \\
\hline & 45 & $30 \mathrm{~min}$ & $10^{-3}$ & 8 to 78 & - & & 3 \\
\hline ces & - & - & - & - & - & & - \\
\hline
\end{tabular}

Heat and chemical treatments were therefore combined in the following ways: (i) spores were heated in water, cooled, and then subjected to chemical treatment; (ii) spores were heated in the presence of chemicals, cooled, and incubated in the same solutions. The results for method I are summarized in Table 2. Maximum germination responses in spores heated to $45{ }^{\circ} \mathrm{C}$ for $4 \mathrm{~h}$ occurred at $\mathrm{I} \times \mathrm{IO}^{-3} \mathrm{M}$ for all compounds except acetone and ethanol, which were at IO M. Among spores heated to $45^{\circ} \mathrm{C}$ for various lengths of time, maximum germination occurred after $4 \mathrm{~h}$, although there was no decrease in those spores heated for 5 and $6 \mathrm{~h}$.

The second method gave different results. Spores incubated in $\mathrm{I} \times \mathrm{IO}^{-3} \mathrm{M}$-furfural for $4 \mathrm{~h}$ at temperatures from 40 to $50{ }^{\circ} \mathrm{C}$ exhibited greater germination than that obtained when the spores were heated in distilled water ( $88 \%$ versus $23 \%$ ) (Fig. 3, I). The temperature optimum was about $2{ }^{\circ} \mathrm{C}$ less when spores were heated in furfural.

The concentrations of furfural, pyrrole and thiophene which produced maximum germination were determined by heating spores for $4 \mathrm{~h}$ at $44{ }^{\circ} \mathrm{C}$ in solutions ranging from $5 \times \mathrm{IO}^{-1}$ to $\mathrm{I} \times \mathrm{IO}^{-5} \mathrm{M}$. The results (Fig. 4) show that the greatest responses for all chemicals were obtained at $\mathrm{I} \times \mathrm{IO}^{-3} \mathrm{M}$, with substantial activation occurring from $1 \mathrm{IO}^{-2}$ to $1 \mathrm{I}^{-4} \mathrm{M}$.

The apparent synergistic action between heat and chemicals was also examined when the duration of heat treatment was varied. In these experiments, spores were heated to $44{ }^{\circ} \mathrm{C}$ in the presence of $\mathrm{I} \times \mathrm{IO}^{-3} \mathrm{M}$-furfural. Maximum germination occurred after $4 \mathrm{~h}$ of heating just as in spores heated in the absence of chemicals (Fig. 5). In contrast to spores heated in water only, germination in spores heated in furfural decreased rapidly when the heat treatment was extended beyond $4 \mathrm{~h}$.

The effect of heat in combination with all the chemicals used before was also tested and is summarized in Table 2. Certain of these chemicals also appeared to act synergistically with 
heat to stimulate germination. Six gave germination percentages from 66 to $88 \%$ while five promoted germination from 42 to $59 \%$. The remaining eight induced germination percentages similar to those recorded for method $\mathrm{I}$.

\section{DISCUSSION}

Compounds which produced the highest frequencies of activation exhibit certain structural or functional similarities. Furfural has a heterocyclic ring with an aldehyde side group; thiophene and pyrrole a heterocyclic ring with no side-chain; and benzaldehyde a benzene ring with an aldehyde side-chain. Therefore, the most active agents tested all share an unsaturated ring system and a small or non-existent side function. Compounds with more complex carbon skeletons, such as 2-methyl furan and 5-hydroxymethyl furfural, reduced germination (59 and $66 \%$ respectively). Further lengthening of the side-chain resulted in even less activity (e.g. $42 \%$ with furfural diacetate and $30 \%$ with 2 -furfural acrolein).

Molecules in the acid form were not effective activators, but as salts, some did stimulate germination. For example, furoic acid at $\mathrm{IO}^{-4} \mathrm{M}$ activated $3 \mathrm{I} \%$ whereas methyl-2-furoate produced $57 \%$ germination. Perhaps the presence of a carboxyl group prevents the basic molecule from stimulating germination.

Since both heat and chemicals alone can break dormancy, and since certain combinations of the two may even act synergistically, the activation mechanism appears to be a complex one. Possibly, several different mechanisms are involved in activation or, if a single process is involved, it responds to widely disparate environmental conditions. One must also consider the possibility that differential response to the treatment may be caused by a heterogeneous spore population (Webster, 1970). Whether our treatments induced an 'activation' phenomenon, such as a gene derepression, or simply removed or de-activated an endogenous inhibitor is not known.

Comparison of constitutionally dormant spores. The response of Coprinus radiatus basidiospores to several stimuli resembles that of Neurospora ascospores (Sussman \& Halvorson, 1966) and Phycomyces sporangiospores (Rudolph, I96I). However, some differences exist. Similarities and differences are summarized in Table 3.

Two differences between germination behaviour in Coprinus radiatus and the other genera are apparent and may be of considerable significance. Neurospora and Phycomyces spores require conditions which are relatively short in duration but rather extreme (i.e. higher temperatures) while Coprinus requires conditions which are longer in duration, but milder.

In nature, Coprinus radiatus spores may germinate in response to the synergistic action of temperature and chemicals. Since only small quantities of these substances are required for germinations, and several of those tested are of wide occurrence in nature, one or more of these compounds may play a role in the natural life-cycle. Dunlop \& Peters (1953) point out that furfural is one of the most widely occurring organic compounds, as it is a breakdown product of pentosans which are components of all higher plant cell walls. Fivehydroxymethyl furfural is readily formed from decomposing hexoses, while furfuryl alcohol is generated directly or indirectly from furfural during fungal spore metabolism (Searles \& French, 1964; Eilers \& Sussman, 1970). Since $C$. radiatus is a coprophilous fungus, its spores pass through the digestive tracts of ruminants where they are subjected to elevated temperatures. Later, in decomposing manure, additional heat is provided, as well as furans. Decomposing manure then, could provide an ideal habitat for the germination of these constitutionally dormant basidiospores. Some of the conditions we have created in culture may, in fact, approximate to the natural environment of germination. 
The authors thank Dr R. Kemp, University of Edinburgh, for his culture of Coprinus. We are indebted to F. E. Ebetino, the director of Eaton Laboratories of Norwich Pharmacal Company, and F. J. Rice, the director of Quaker Oats Research Laboratories, for their generous supply of furans. This work is part of a thesis submitted by G.L.M. to the University of South Florida in partial fulfilment of the requirements for the Master of Science degree in Botany.

\section{REFERENCES}

Dunlop, A. P. \& Peters, F. N. (1953). The Furans. American Chemical Society Monograph. New York: Reinhold Publishing Corporation.

Eilers, F. I. \& Sussman, A. S. (1970). Conversion of furfural to furoic acid and furfuryl alcohol by Neurospora ascospores. Planta 94, 253-264.

Gans, M. \& Masson, M. (I969). Structure fine du locus ur-I chez Coprinus radiatus. Molecular and General Genetics 105, I64-181.

Lange, M. (1952). Species concept in the genus Coprinus. Dansk botanisk Arkiv 14, 7-162.

LingapPa, B. T., Lingappa Y. \& Turian, G. (1970). Phenethyl alcohol induced germination of ascospores of Neurospora. Archiv für Mikrobiologie 72, 97-105.

RaJu, N. B. \& LU, B. C. (1970). Meiosis in Coprinus. III. Timing of meiotic events in C. Lagopus (sensu Buller). Canadian Journal of Botany 48, $2183-86$.

RuDolPH, H. (1961). Über die keimungsfördende Wirkung verschiedener Acetaldehyd-Präperate. Zeitschrift für Naturforschung 16b, 61 I-614.

SEARLES, R. B. \& FRENCH, R. C. (1964). Conversion of furfural and cinnamaldehyde by uredospores of wheat stem rust and associated bacteria. Botanical Gazette 125, I46-148.

Sussman, A. S. (1953). The effect of heterocyclic and other compounds upon the germination of ascospores of Neurospora tetrasperma. Journal of General Microbiology 8, 21 I I-21 6.

Sussman, A. S. (1965). Physiology of dormancy and germination in the propagules of cryptogamic plants. In Encyclopedia of Plant Physiology, vol. 15, p. 933. Berlin: Springer Verlag.

Sussman, A. S. \& Halvorson, H. O. (1966). Spores: Their Dormancy and Germination, p. 345. New York and London: Harper and Row.

Sussman, A. S., Lowry, R. J. \& TYrRell, E. (1959). Activation of Neurospora ascospores by organic solvents and furans. Mycologia 5I, 237-247.

Webster, J. (1970). Coprophilous fungi. Transactions of the British Mycological Society 54, I6I-180. 